Bangladesh J. Plant Taxon. 25(2): 123-133, 2018 (December)

(C) 2018 Bangladesh Association of Plant Taxonomists

\title{
SPECIES DELINEATION OF THE GENUS DIPLAZIUM SWARTZ (ATHYRIACEAE) USING LEAF ARCHITECTURE CHARACTERS
}

\author{
JENNIFER M. CONDA ${ }^{1}$ AND InOCEnCIO E. Buot, $\mathrm{JR}^{2}$ \\ Department of Science and Technology-Forest Products Research and Development Institute, \\ Los Baños, Laguna, Philippines
}

Keywords: Leaf architecture; Taxonomic marker; Cladodromous; Reticulodromous; Craspedodromous; Cophenetic correlation.

\begin{abstract}
The present study was conducted to delineate Diplazium Swartz species based on leaf architecture. Using PAleontological STatistics (PAST), a cluster and Principal Component Analysis of leaf architecture characters of 27 selected Diplazium species at the Philippine National Herbarium (PNH) was done. The dendogram (cophenetic correlation $=0.8436$ ) and principal component analysis supported the four clusters of Diplazium using leaf architecture characters. At Gower distance of 0.25 , Diplazium species were categorized as: Cluster 1 (Cladodromous - short stalked, stout and massive $1^{\circ}$ vein); Cluster 2 (Reticulodromous - long stalked, moderate $1^{\circ}$ vein); Cluster 3 (Craspedodromous - long stalked, stout to massive $1^{\circ}$ vein); and Cluster 4 (Craspedodromous - short stalked, stout to massive $1^{\circ}$ vein). The unifying characters were apex shape, base symmetry and $1^{\circ}$ vein category, while the significant differentiating characters were $2^{\circ}$ vein angle of divergence and variation in the $2^{\circ}$ vein angle of divergence, $3^{\circ}$ vein category, $3^{\circ}$ vein angle of divergence, variation in $3^{\circ}$ vein angle of divergence, $3^{\circ}$ vein spacing and lobation. The successful delineation of Diplazium species proved that leaf architecture can be a good taxonomic marker and could be an alternative way of identifying species in the absence of sori.
\end{abstract}

\section{Introduction}

Diplazium Swartz consists of about 400 species distributed mainly in the tropics and sparingly in temperate forest (Kramer et al., 1990). Copeland (1947) enumerated 62 Diplazium species in the Philippines. Meanwhile, 49 species of Diplazium were listed in Co Digital Flora of the Philippines (http://www. philippineplants.org/Families/Pteridophytes.html). Among genera under Athyriaceae, Diplazium species were always included in ethnobotanical studies (Rai et al., 2005; Kumari et al., 2011; Sujarwo et al., 2014) as sources of food, medicine and decorative materials (Vasudeva, 1999). In Asian and Filipino dishes, Diplazium esculentum is served as salad, dietary staple, base for spicy condiments and vegetable (Kayang, 2007). As medicine, Diplazium species were noted for their antibacterial (Amit et al., 2011), phytochemicals (Sivaraman et al., 2011), antimicrobial and cytotoxic (Akler et al., 2014), analgesic (Chawla et al., 2015), and antioxidant properties (Pradhan et al., 2015).

Despite of the well-studied uses of genus Diplazium their taxonomic classification and identification is still controversial among taxonomists and pteridologists. Some of the problems in accurate identification of the genus included insufficient data (Kramer et al., 1990) and continuous changes in taxonomic classification and morphological variations through apparently intermediate

\footnotetext{
${ }^{1}$ Corresponding author. Email: jhen_0421@yahoo.com; jennifermconda@gmail.com

${ }^{2}$ Institute of Biological Sciences, College of Arts and Sciences, University of the Philippines Los Baños, Los Baños, Laguna, Philippines.
} 
forms, which are commonly regarded as putative hybrids (Takamiya et al., 1999). The chance of misidentification is higher especially during field surveys and actual identification because Diplazium species are morphologically similar to their sisters Athrium and Deparia (Kato, 1977) and to some members of Woodsiaceae and Polypodiaceae to which Diplazium was formerly circumscribed (Smith et al., 2006). Unconscious identification of Diplazium might lead to collection of wrong specimens, thus cannot satisfied the intent use and worst can be hazardous to human health or even cause death. The lack of knowledge or information when collecting for medicinal purposes, toxin-containing plants can result in misidentification with grave consequences (Voncina et al., 2014).

Thus, several classification system and scholarly works were done to differentiate, delineate and investigate the phylogenetic relationship of Diplazium species. These include DNA sequencing (Wei et al., 2013), spore morphology (Praptosuwiryo et al., 2007), stelar anatomy (Praptosuwiryo and Darnaedi, 2014), and cytology and reproduction (Takamiya et al., 1999). Takhtajan (1996) pointed out that molecular methods are not necessarily a universal remedy in elucidating the evolution of a certain taxon because molecular characters are also subjected to evolutionary convergence, parallelism and reversal besides random changes in DNA sequence. Further, molecular studies are expensive and not feasible in low cost-funded projects and inefficient in field surveys where actual identification is necessary.

One taxonomic tool useful in differentiating angiosperm taxa and also considered in ferns is leaf architecture, which is defined as the placement and form of elements constituting the outward expression of leaf structure, including venation pattern, marginal configuration, leaf shape, and gland position (Hickey, 1973). Pacheco and Moran (1999) resurrected Callipteris in their revision of the Neotropical species, and found diagnostic characters such as anastomosing veins and petiole/rachis scales with bifid-toothed margins. Recent studies on fern leaf architecture were done in the genus Ophioglossum (Magrini and Scoppola, 2010) and Lygodium (Shinta et al., 2012). Leaf architecture of fern species such as Blechnum binervatum, Ctenitis falciculata, Magalastrum connexum, Microgramma squamulosa and Serpocaulon catharinae were studied by Larcher et al., (2013).

Though, leaf plasticity had been an issue on the use of leaf architecture as important taxonomic marker it proved its usefulness in differentiating angiosperm. As vascular plants with distinct venation pattern, ferns are expected to have similar stability in terms of venation pattern. In fact, fern stipes are reinforced by a very stiff sclerenchyma consisting of dead cells with nonextensible rigid cell walls (Leroux, 2012) providing support and preserving the leaf architecture (Larcher et al., 2013). In addition, ferns have persisted through their evolutionary history and represent highly successful forms in both past and present (Pittermann, 2010). Therefore, this study aims to delineate some Diplazium species of the Philippines using leaf architecture characters.

\section{Materials and Methods}

The leaf architecture characters of 27 Diplazium species at the Philippine National Herbarium (PNH) were summarized in Table 1 (leaf morphology) and Table 2 (venation pattern). The morphological leaf characters and venation pattern (Conda and Buot, 2017) were used to determine the species delineation of the genus Diplazium through Cluster and Principal Component Analysis of Paleontological Statistics (PAST). The distance measure and clustering method used were Gower and Unweighted Pair-Group Method of Arithmetic Mean (UPGMA), respectively. 
For data analysis, 21 characters were selected for each species and each character was assigned to a corresponding legend as follows: LO1-6 for leaf organization, BlCl1-7 for blade class, Sh1-3 for shape, ApSh1-2 for apex shape, BaSh1-4 for base shape, BaAn1-3 for base angle, BaSy1-2 for base symmetry, Mar1-3 for margin, St1-2 for stalk, Lob1-4 for lobation, PVC1 for $1^{\circ}$ vein category, PVS1-4 for $1^{\circ}$ vein size, SVC1-3 for $2^{\circ}$ vein category, SAD1-6 for $2^{\circ}$ vein angle of divergence, SVAD1-4 for $2^{\circ}$ vein, variation in angle of divergence, SVS1-3 for $2^{\circ}$ vein spacing, TVC1-3 for $3^{\circ}$ vein category, TAD1- 6 for $3^{\circ}$ vein angle of divergence, TVAD1-3 for $3^{\circ}$ vein, variation in angle of divergence, TVS1-3 for $3^{\circ}$ vein spacing, and AR1-2 for areole.

\section{Results and Discussion}

Leaf architecture characters of 27 Diplazium species are presented in Table 1. These characters varied especially in terms of L:W ratio, blade class, base angle and lobation. This interspecific variation illustrated that these characters could be good indicators of identification. The dendrogram (Fig. 1) with cophenetic correlation of 0.8436 and principal component analysis (Fig. 2) consistently separated Diplazium species into four clusters. At Gower distance of 0.25, Diplazium species were grouped into 4 clusters namely, Cluster 1 (Cladodromous - short stalked, stout and massive $1^{\circ}$ vein); Cluster 2 (Reticulodromous - long stalked, moderate $1^{\circ}$ vein); Cluster 3 (Craspedodromous - long stalked, stout and massive $1^{\circ}$ vein) and Cluster 4 (Craspedodromous short stalked, stout to massive $1^{\circ}$ vein).

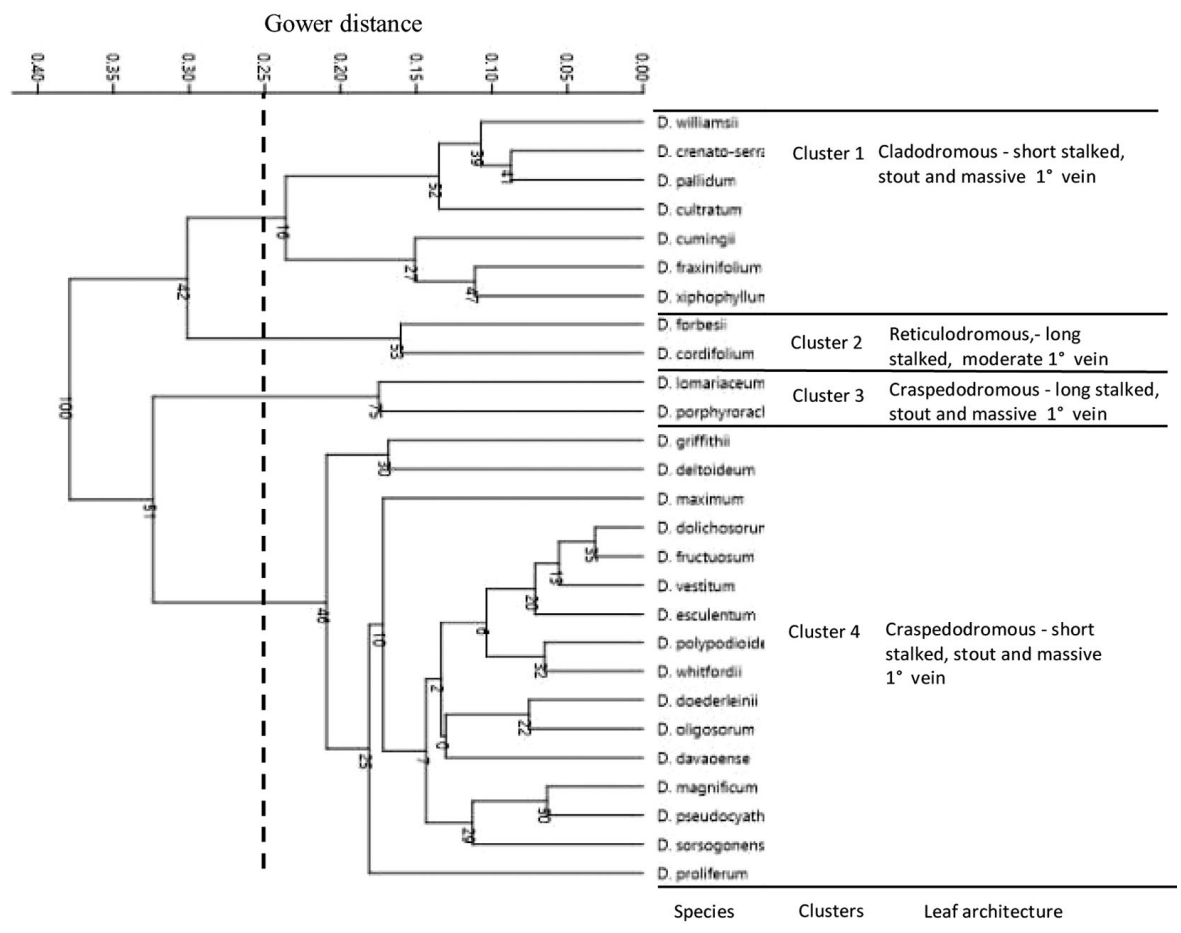

Fig. 1. Dendrogram of the 27 Diplazium species constructed by Unweighted Pair-Group of Arithmetic Mean (UPGMA) clustering and Bower using the Paleontological Statistics software. With cophenetic correlation of 0.8436 and gower distance of 0.25 , four cluster were identified: Cluster 1 (Cladodromous short-stalked, stout and massive $1^{\circ}$ vein); Cluster 2 (Reticulodromous - long stalked, moderate $1^{\circ}$ vein); Cluster 3 (Craspedodromous - long stalked, stout and massive $1^{\circ}$ vein) and Cluster 4 (Craspedodromous - short stalked, stout to massive $1^{\circ}$ vein). 


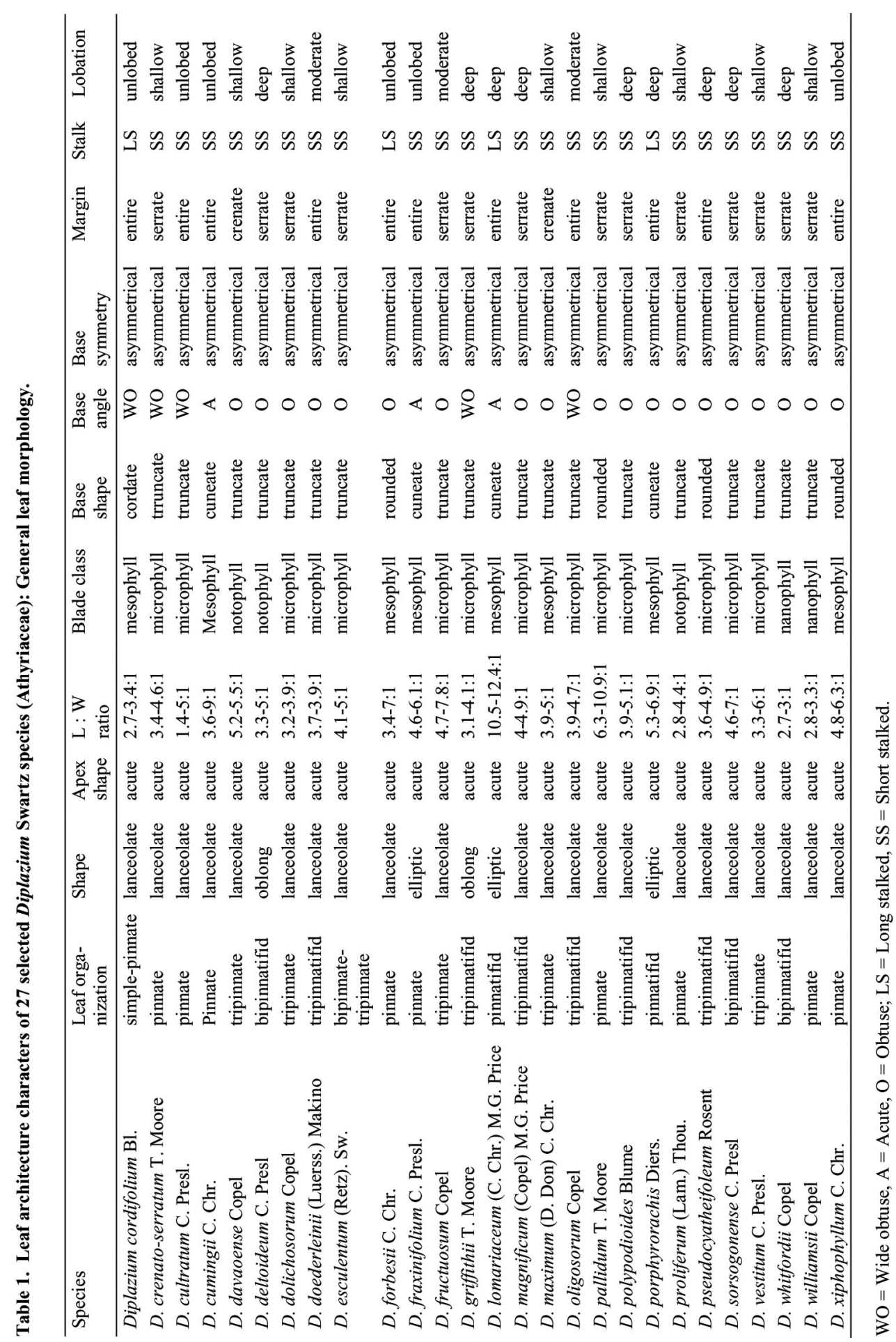




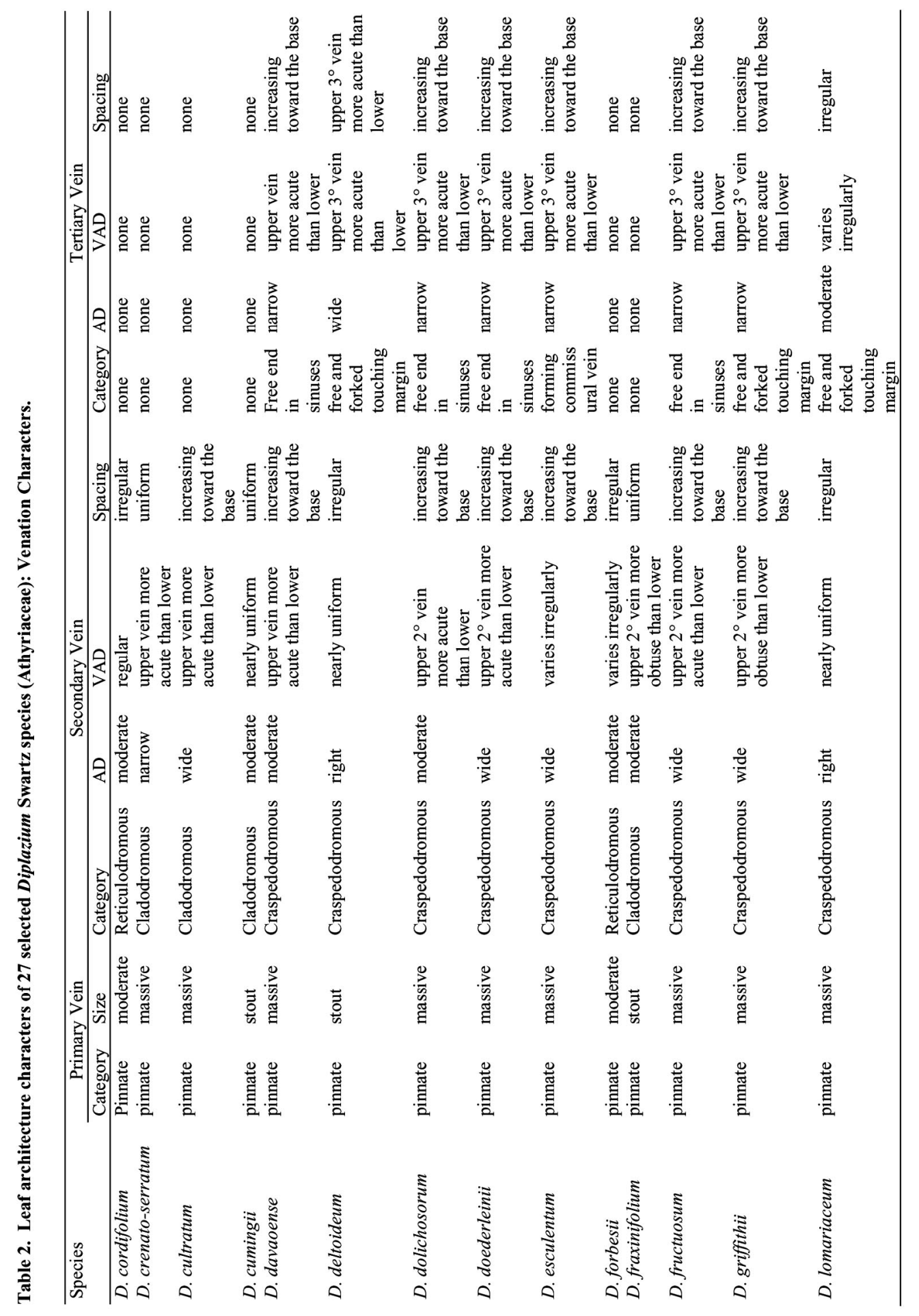




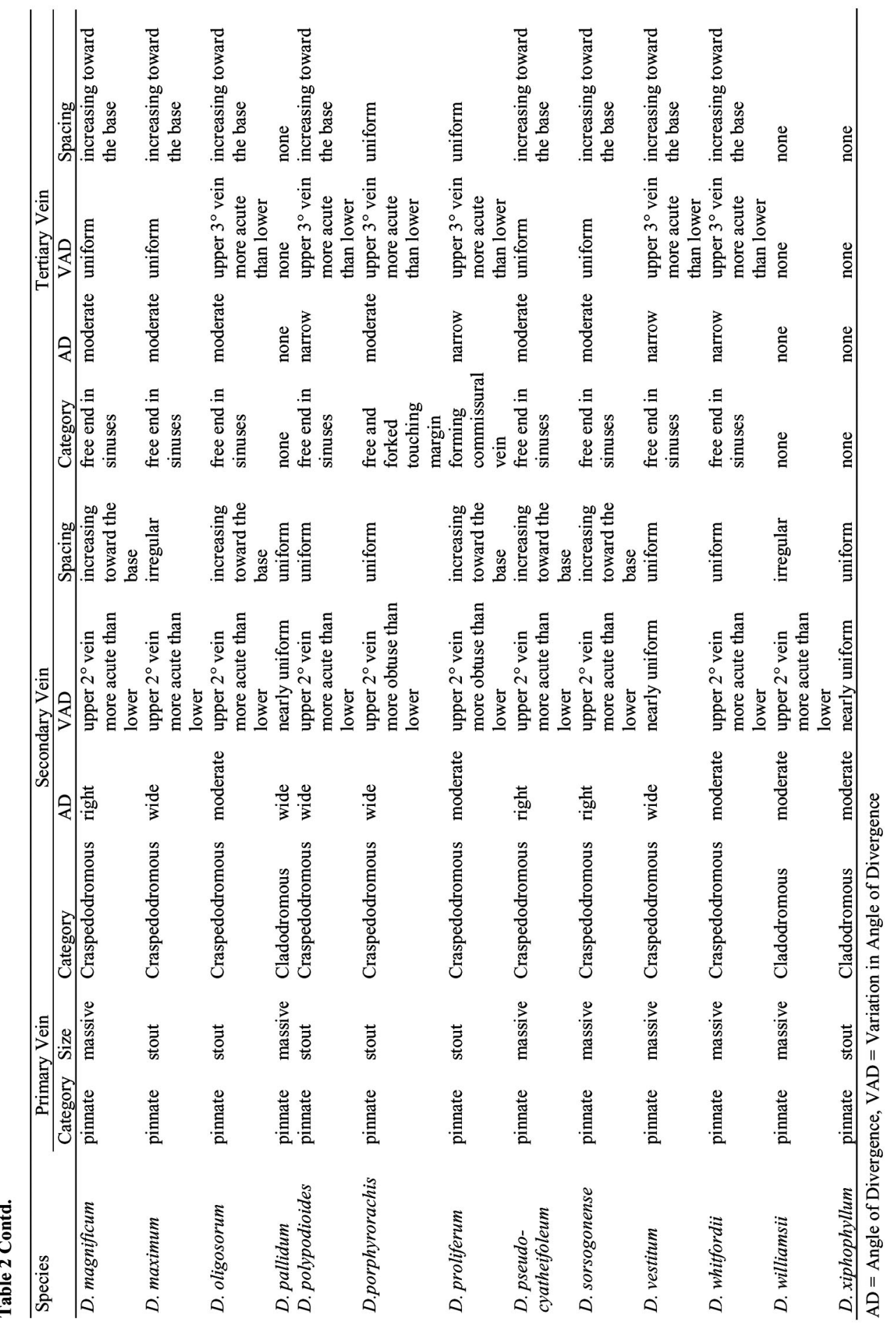




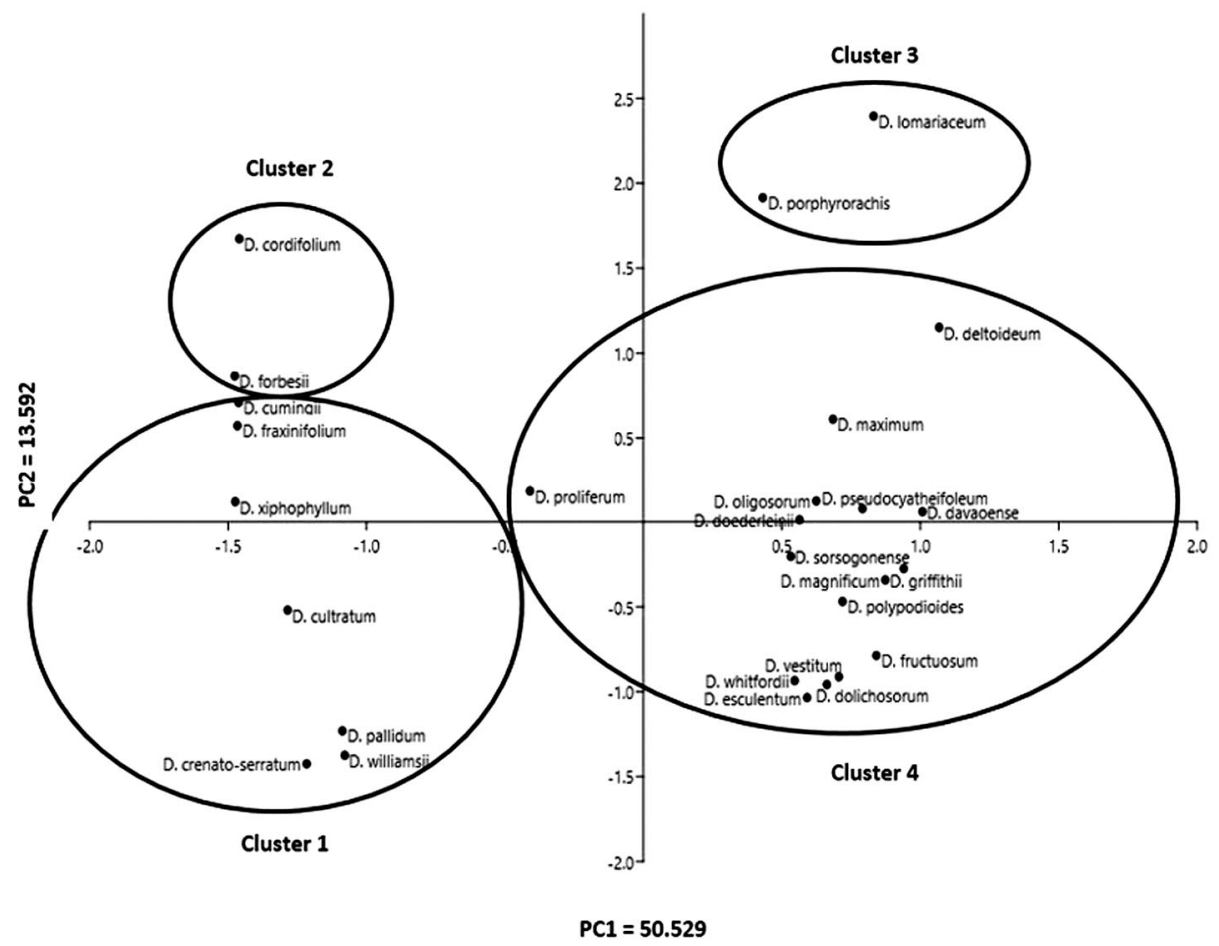

Fig. 2. Principal Component Analysis of 27 Diplazium species using PAleotological STatistics (PAST) software. Four clusters were classified: Cluster 1 (Cladodromous - short stalked, stout and massive $1^{\circ}$ vein); Cluster 2 (Reticulodromous - long stalked, moderate $1^{\circ}$ vein); Cluster 3 (Craspedodromous - long stalked, stout and massive $1^{\circ}$ vein) and Cluster 4 (Craspedodromous - short stalked, stout to massive $1^{\circ}$ vein).

Cluster 1, the Cladodromous - short stalked, stout to massive $1^{\circ}$ vein: It includes $D$. williamsii Copel, D. crenato-serratum T. Moore, D. pallidum T. Moore, D. cultratum C. Presl., D. cumingii C. Chr. and D. xiphophyllum C. Chr. Sample line drawings of species under Cluster 1 (Figs. 3a3c) were lifted from Conda and Buot (2017). Based on the illustrations, common leaf architecture characters were: pinnate leaf arrangement, lanceolate shape, acute apex, symmetrical base, entire and serrate margin, unlobed to shallow lobation, short stalked, pinnate $1^{\circ}$ vein, stout to massive $1^{\circ}$ vein size, cladodromous $2^{\circ}$ vein category and absence of areole. In this cluster there is one outlier, $D$. fraxinifolium, which is reticulodromous.

Cluster 2, the Reticulodromous, long stalked - moderate $1^{\circ}$ vein: Cluster 2 includes D. cordifolium Bl. (Fig. 3d) and D. forbesii C. Chr. (Fig. 3e). These species showed pinnate leaf arrangement, lanceolate leaf shape, acute apex, asymmetrical base, entire margin, long-stalked, unlobed blade, mesophyllous blade class, pinnate $1^{\circ}$ vein, reticulodromous $2^{\circ}$ vein, moderate $2^{\circ}$ vein angle of divergence and presence of areole. The two species differed in variation in $2^{\circ}$ vein angle of divergence. The former exhibits nearly uniform $2^{\circ}$ vein angle of divergence while irregular in the latter. This cluster was found consistent with the classification of Diplazium species using stelar anatomy of stipe (Praptosuwiryo and Darnaedi, 2014) and spore morphology specifically perine ornamentation (Praptosuwiryo et al., 2007). 

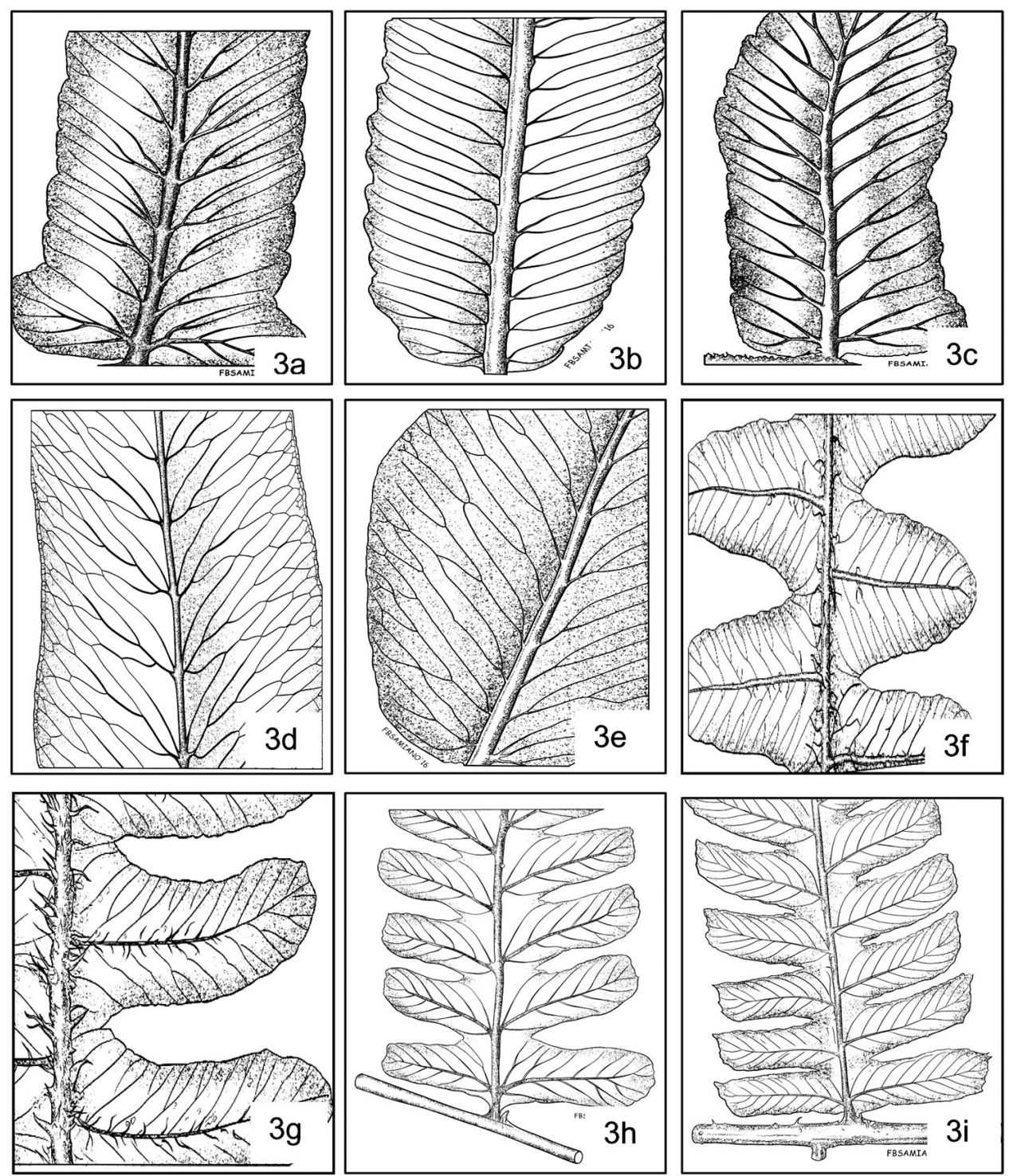

Fig. 3. Line drawings of Diplazium species with different venation pattern. Cladodromous - short stalked, stout to massive $1^{\circ}$ vein venation pattern: $D$. crenato-serratum T. Moore (3a), D. pallidum T. Moore (3b) and D. cutratum C. Presl (3c). Reticulodromous - short stalked, moderate $1^{\circ}$ vein: $D$. cordifolium Blume (3d) and $D$. forbesii C. Chr. (3e). Craspedodromous - long stalked, stout and massive $1^{\circ}$ vein: $D$. lomariaceum (C. Chr.) M.G. Price (3f) and D. porphyrorachis Diers. (3g). Craspedodromous - short stalked, stout to massive $1^{\circ}$ vein: D.oligosorum Copel (3h) and D. polypodioides Blume (3i).

Cluster 3, the Craspedodromous - long stalked, stout and massive $1^{\circ}$ vein: This cluster consists of D. lomariaceum (C. Chr.) M.G. Price (Fig. 3f) and D. porphyrorachis Diers (Fig. 3g). They exhibit pinnatifid lamina, elliptic shape, acute apex, cuneate and asymmetrical base, entire margin, long stalked, deeply lobed, mesophyllous blade class, pinnate $1^{\circ}$ vein, craspedodromous $2^{\circ}$ vein, right $2^{\circ}$ vein angle of divergence, free and forked touching margin $3^{\circ}$ vein, moderate $3^{\circ}$ 
vein angle of divergence and absence of areoles. D. porphyrorachis differs by having stout $1^{\circ}$ vein size, uniform $2^{\circ}$ and $3^{\circ}$ vein spacing and upper $3^{\circ}$ vein more acute than lower variation in $3^{\circ}$ vein angle of divergence. While $D$. lomariaceum showed a massive $1^{\circ}$ vein size, irregular $2^{\circ}$ and $3^{\circ}$ vein spacing and irregular variation in $3^{\circ}$ vein angle of divergence. This group was strongly supported using spore morphology (Praptosuwiryo et al., 2007).

Cluster 4, the Craspedodromous - short stalked, stout to massive $1^{\circ}$ vein: It includes majority of Diplazium species (16 individuals) namely, D. griffithii T. Moore, D. deltoideum (C. Presl.), D. maximum (D. Don) C. Chr., D. proliferum (Lam.) Thours., D. esculentum (Retz.) Sw., D. oligosorum (Copel), D. sorsogonense (C. Presl.) C. Presl., D. magnifium (Copel) M.G. Price, D. pseudocyatheifolium Rosent., D. doederleinii (Luerss.) Makino, D. whitfordii Copel, D. polypodioides (Blume), D. vestitum C. Presl., D. fructuosum (Copel), D. dolichosorum (Copel) and D. davaoense (Copel). Sample drawings (Figs. 3h \& 3i) from Conda and Buot (2017) were incorported to emphasize the common leaf architecture characters namely, lanceolate to rarely oblong leaf shape, acute apex, truncate base, obtuse to wide obtuse base angle, asymmetrical base, pinnate $1^{\circ}$ vein, stout to massive $1^{\circ}$ vein size, upper $2^{\circ}$ vein more acute than lower variation in angle of divergence and absence of areoles. At Gower distance of $0.19, D$. griffithii and D. deltoideum, having oblong pinnule, was separated from the lanceolate group. Among the lanceolate group, only $D$. esculentum and $D$. proliferum possessed $3^{\circ}$ vein forming commissural vein, while the rest have free end in sinuses $3^{\circ}$ vein. This cluster coincides mostly with the work of Wei et al. (2013) using DNA sequencing of Diplazium from different geographical areas. Most species in this study fell under clade IV, subclade E (Diplazium species with short branches connecting deeper nodes and long branches leading to tip - occuring in Southeast Asia and adjoining regions) of Wei et al., (2013) phylogram. The analysis of the leaf architecture characters of D. davaoense, D. esculentum and D. doederlenii (cluster 4) revealed similarities with subclade H (Wei et al., 2013) possibly because these species are Asiatic in nature.

Leaf architecture, particularly the venation pattern, is a good taxonomic tool in delineating Diplazium species. Consistency in groupings with spore morphology, stelar anatomy and DNA sequencing proved leaf architecture's usefulness in the classification system for Diplazium species. The dendrogram (cophenetic coefficient $=0.8436$ ) and principal component analyses highly supported the four clusters of Diplazium using leaf architecture characters, viz. Cluster 1 (Cladodromous - short stalked, stout and massive $1^{\circ}$ vein); Cluster 2 (Reticulodromous - long stalked, moderate $1^{\circ}$ vein); Cluster 3 (Craspedodromous - long stalked, stout and massive $1^{\circ}$ vein) and Cluster 4 (Craspedodromous - short stalked, stout to massive $1^{\circ}$ vein). The unifying characters in the genus are apex shape, base symmetry and $1^{\circ}$ vein category, whereas $2^{\circ}$ vein angle of divergence and variation in $2^{\circ}$ vein angle of divergence, $3^{\circ}$ vein category, $3^{\circ}$ vein angle of divergence, variation in $3^{\circ}$ vein angle of divergence, $3^{\circ}$ vein spacing and lobation are the differentiating features. This study has proved that identification of sterile specimen is now feasible with leaf architecture.

\section{Acknowledgments}

We would like to thank the Department of Science and Technology and Forest Products Research and Development Institute for providing scholarship and allowing the senior author to pursue graduate degree studies at the University of the Philippines, Los Baños and the Philippine National Museum, particularly the Philippine National Herbairum, for access to their botanical collections. We also extend our deepest gratitude to Dr. Tito Evangelista, John Rey Callado, Emerita R. Barile and Froilan B. Samiano for the assistance during the course of the study. 


\section{References}

Akler, S., Hossain, M.M., Ara, I. and Akhtar, P. 2014. Investigation of in vitro antioxidant, antimicrobial and cytotoxic activity of Diplazium esculentum (Rets.) Sw. International J. Adv. Pharm. Biol. \& Chem. 3(3): 723-733.

Amit, S., Sunil, K. and Arvind, N. 2011. Antibacterial activity of Diplazium esculentum Retz.) Sw. Phcog J. 3(21): 77-79.

Chawla, S., Ram, V., Semwal, V.A. and Singh, R. 2015. Analgesic activity of medicinally important leaf of Diplazium esculentum. Afr. J. Pharm. Pharmacol. 9(25): 628-632.

Co Digital Flora of the Philippines. http://www.philippineplants.org/Families/Pteridophytes.html.> Retrieved on 17 March 2018.

Conda, J.M. and Buot Jr., I.E. 2017. Leaf architecture of selected Philippine Diplazium Swartz species (Athyriaceae). THNHMJ. 11(2): 57-76.

Copeland, E.B. 1947. Genera Filicum. Waltham MA: Chronica Botanica Company.

Hickey, L.J. 1973. Classification of the architecture of dicotyledonous leaves. Am. J. Bot. 60(1): 17-33.

Kato, M. 1977. Classification of Athyrium and allied genera of Japan. Bot. Mag. (Tokyo) 90: 23-40.

Kayang, H. 2007. Tribal knowledge on wild edible plants of Meghalaya, Northeast India. Indian J. Trad. Knowledge 6: 177-181.

Kramer, K.U., Holttum, R.E., Moran, R.C. and Smith, A.R. 1990. Dryopteridaceae. In: Kramer K.U. and Green, P.S. (Eds), Pteridophytes and Gymnosperms. Berlin: Springer-Verlag, pp. 101-144.

Kumari, P., Otaghvari, A.M., Govindapyari, H., Bahuguna, Y.M. and Uniyal, P.I. 2011. Some ethnomedicinally important pteridophytes of India. Int. J. Med. Arom. Plants 1(1): 18-22.

Larcher, L., Boeger, M.R.T. and Silveira, T.I. 2013. Leaf architecture of terrestrial and epiphytic ferns from an Araucaria forest in southern Brazil. Botany 91: 768-773.

Leroux, O. 2012. Collenchyma: a versatile mechanical tissue with dynamic cell walls. Ann Bot. 110(6): 1083-1098.

Magrini, S. and Scoppola, A. 2010. Geometric morphometrics as a tool to resolve taxonomic problems: the case of Ophioglossum species (ferns). In: Nimis, P.L. and Lebbe, R.V. (Eds), Tools for identifying biodiversity: progress and problems, pp. 251-256.

Pacheco, L. and Moran, R.C. 1999. Monograph of the Neotropical species of Callipteris with anastomosing veins (Woodsiaceae). Brittonia 51: 343-388.

Pittermann, J. 2010. The evolution of water transport in plants: an intergrated approach. Geobiology 8: $112-139$.

Pradhan, S., Manivannan, S. and Tamang, J.P. 2015. Proximate, mineral composition and antioxidant properties of some wild leafy vegetables. J. Sci. Ind. Res. 74: 155-159.

Praptosuwiryo, T.N., Kato, M. and Darnaedi, D. 2007. Specific delimitation and relationship among species of Diplazium based on spore morphology. Floribunda 3(3): 57-84.

Praptosuwiryo, T.N. and Darnaedi, D. 2014. The stellar anatomy of stipe and its taxonomic significance in Diplazium (Athyriaceae). Floribunda 4(8): 195-201.

Rai, A.K., Sharma, R.M. and Tamang, J.P. 2005. Food value of common edible plants of Sikkim. J. Hill Res. 18(2): 99-103.

Shinta, R.N., Arbain, A. and Syamsuardi, D. 2012. The morphometrics study of climbing ferns (Lygodium) in West Sumatra. J. Bio. J. Biol. Universitas Andalas 1(1): 45-53.

Sivaraman, M., Johnson, N. and Babu, A. 2011. Phytochemical studies on selected species of Diplazium from Tirunelveli Hills, Western Ghats, South India. Int. J. Basic \& Appl. Biol. 5(3\&4): 241-247.

Smith, A.R., Pryer, K.M., Schuettpelz, E., Korall, P., Schneider, H. and Wolf, P. 2006. A classification for extant ferns. Taxon 55(3): 705-731.

Sujarwo, W., Lugrayasa, I.N. and Caneva, G. 2014. Ethnobotanical study of edible ferns used in Bali, Indonesia. APJSAFE 2(2): 1-4. 
Takhtajan, A. 1996. Diversity and Classification of Flowering Plants. New York: Columbia University Press, pp. 231-234.

Takamiya, M., Takaoka, C. and Ohta, N. 1999. Cytological and reproductive studies on Japanese Diplazium (Woodsiaceae: Pteridophyta): apomictic reproduction in Diplazium with evergreen bi- to tri-pinnate leaves. J. Plant Res. 112: 419-436.

Vasudeva, S.M. 1999. Economic importance of Pteridophytes. Indian Fern J. 16(1-2): 130- 152.

Voncina, M., Baricevic, D. and Brvar, M. 2014. Adverse effect and intoxications related to medicinal/ harmful plants. Acta Agri. Slov. 103(2): 263-270.

Wei, R., Schneider, H. and Zhang, X.C. 2013. Towards a new circumscription of the twinsorus-fern genus Diplazium (Athyriaceae): a molecular phylogeny with morphological implications and infrageneric taxonomy. Taxon 62(3): 441-457.

(Manuscript received on 7 June 2017; revised on 11 October 2018) 